\title{
ANALYSIS OF FINANCIAL RATIOS FOR PREDICTING BANKRUPTCY IN SMES LISTED ON PEFINDO25
}

\author{
Vitalia Fina Carla Rettobjaan \\ Faculty of Social Technology Business and Humanities, Bali International University \\ vitaliacarlarettobjaan@gmail.com
}

Received: April, 2020; Accepted: May, 2020; Published: September, 2020

DOI: https://doi.org/10.24123/jmb.v19i2

\begin{abstract}
This study aims to analyze the Financial Ratio for Predicting Bankruptcy. The sample used in this study are SMEs according PEFINDO25 period 2013 to 2017. The independent variables in this study is liquidity, profitability, debt structure, solvency and activity ratio; and control variables is size and age, as well as the dependent variable is bankruptcy. The amount of sample in this study 32 companies PEFINDO25 by using purposive sampling. The method of data analysis is done by using logistic regression with SPSS version 23. The result of this research showed that liquidity, profitability and age has significant negative effect on bankruptcy. Debt structure has significant positive effect on bankruptcy. While solvency, activity ratio and size does not significantly effect on bankruptcy.
\end{abstract}

Keywords: Activity ratio, Bankruptcy, Debt structure

\begin{abstract}
Abstrak
Penelitian ini bertujuan untuk menganalisis Rasio Keuangan untuk memprediksi Kebangkrutan. Sampel penelitian ini adalah perusahaan UKM menurut PEFINDO25 pada periode 2013 hingga 2017. Variabel independen dalam penelitian ini adalah liquidity, profitability, debt structure, solvency dan activity ratio, dan variabel kontrol yaitu size dan age, serta variable dependennya adalah bankruptcy. Jumlah yang menjadi sampel dalam penelitian ini 32 perusahaan PEFINDO25 dengan menggunakan purposive sampling. Metode analisis data dilakukan dengan menggunakan regresi logistic. Hasil penelitian menunjukkan bahwa liquidity, profitability dan age memiliki pengaruh negatif dan signifikan terhadap bankruptcy. Debt structure memiliki pengaruh positif dan signifikan terhadap bankruptcy. Sedangkan solvency, activity ratio dan size tidak memiliki pengaruh terhadap bankruptcy.
\end{abstract}

Kata Kunci: Activity ratio, Bankruptcy, Debt structure

\section{INTRODUCTION}

The economy is an important aspect in determining the success and welfare of the people in a country. Of course there are two things that are very closely related to advancing the country's economy namely human resources and how many jobs are available, in this case how many companies are in the country both large-scale companies to small-scale companies, one of which is small business medium (UKM) in Indonesia. According to Law No. 20 of 2008 concerning Micro, Small and Medium Enterprises, what is meant by Small Business is a productive economic business that 
stands alone, and is carried out by individuals or business entities that are not subsidiaries, which have a net worth of more than Rp 50,000,000.00 up to a maximum of Rp 500,000,000.00 excluding land and business premises. Then have annual sales results of more than IDR $300,000,000.00$ up to a maximum of IDR 2,500,000,000.00. While Medium Business is a productive economic business that stands alone, carried out by individuals or business entities that are not subsidiaries, which have a net worth of more than Rp. 500,000,000.00 up to a maximum of Rp. 10,000,000.0000.00 excluding land and buildings place of business. As well as having annual sales results of more than $\mathrm{Rp} 2,500,000,000.00$ up to a maximum of $\mathrm{Rp} \mathrm{50,000,000,000.00}$ (Kristiyanti 2012).

In contrast to the aforementioned law, the IDX together with PEFINDO and Investor Daily has inaugurated a new stock index called the PEFINDO25 index, where this index is specifically made for Small and Medium Enterprises (SMEs) consisting of 25 shares, which selected based on fundamental, technical or liquidity criteria, the share listing period is reviewed every six months of the year, to be exact in FebruaryJuly and August-January. One of the criteria of the PEFINDO25 index, which is meant is that companies must have total assets that do not exceed Rp 5,000,000,000,000.00 (five trillion rupiah) (www.pefindo.com).

Every company must have potential business and financial risks, including Small and Medium Enterprises (SMEs), so that to face the country's developing economy, SMEs are guided to improve the welfare of shareholders, and other interested parties, and meet the increasingly complex demands of society. Because the economic conditions in Indonesia are still uncertain, this results in a high risk of bankruptcy. Potential bankruptcy is a concern for various parties, because bankruptcy is an important matter in stakeholders such as customers, suppliers, investors, creditors, and company employees (Cultrera et al. 2017).

According to Lukason et al. (2016), the perceived impact of bankruptcy is financial failure, unemployment, and a bad economic situation that causes great losses to be experienced by creditors (banks), investors, shareholders, suppliers, company employees, customers, and the whole community. The first signs of bankruptcy of a company is the weakening of the company in generating profits or in other words as a failure in obtaining profits. Bankruptcy as a failure can be interpreted in two parts, namely (1) financial failure which means a company does not have sufficient cash flow to meet principal repayments on a certain date; (2) economic failure means that a company's revenue cannot cover the company's own costs, in the sense that the rate of profit (profit) is smaller than the cost of capital of the company (Nouiri \& Soltani 2017). Therefore, bankruptcy prediction analysis (BPA), is a very important thing to do by companies from the beginning to identify financial stability in the company (Cultrera \& Berdart 2016).

According to Cultrera \& Berdart (2016) related to bankruptcy predictions there are four approaches used including: economic approach, organizational and managerial approach, strategic approach and financial approach. This research will focus on the financial approach by analyzing and considering financial ratios that reflect the signs that arise from the true causes of bankruptcy. The financial approach can also find relevant financial ratios to the variables of the z-score model used in this study which are generally obtained from the company's financial statements, including profitability ratios, liquidity ratios, debt structures, solvency ratios and activity ratios to predict bankruptcy in certain time horizon (Cultrera et al. 2017). 


\section{RESEARCH METHODS}

This research is an analytic study with cross-sectional design. The population in this study are 69 SME companies that have been listed on PEFINDO25 listed on the Indonesia Stock Exchange in 2013-2017. Sampling in this study uses a purposive sampling method, which is a sampling method based on the determination of certain characteristics and criteria that have been determined. The sample used was $32 \mathrm{SME}$ companies during 2013-2017 and had total assets not exceeding Rp 5 trillion. The variables of this study consisted of 3 independent variables, control variables and dependent variables. The independent variables used in this study are Liquidity, Debt Structure, Solvency and Activity ratio (Cultrera \& Bredart 2016). The control variables used in this study are Size and Age (Cultrera \& Bredart 2016). The dependent variable used in this study is Bankruptcy, where this study will predict bankruptcy or bankruptcy in SME companies so it can be measured with a dummy variable where there are 2 sample companies, namely a healthy company is given a value of 0 and a bankrupt company is given a value of 1 .

Before giving this value, measurements are made using the Almant's Z-Score model to find out which companies are going bankrupt and which companies are not going bankrupt. Because secondary data was taken from all SME companies that have been registered at PEFINDO25, where SME companies comprise various sectors not only the manufacturing sector, but the service and investment sectors, the authors use the Almant's Z-Score 1995 model. In this model there are four financial ratios that can be used to assess whether a company is said to be healthy or unhealthy or towards bankruptcy. The measurement of this variable is as follows (Odibi et al. (2015) instead of Cultrera \& Bredart (2016)).

Information:

$$
\begin{array}{ll}
\text { Z } & =\text { Bankruptcy Index } \\
\text { X1 } & =\text { Working Capital/Total Asset } \\
\text { X2 } & =\text { Retained Earnings/Total Asset } \\
\text { X3 } & =\text { Earnings Before Interest and Taxes/Total Assets } \\
\text { X4 } & =\text { Book Value of Equity/Book Value of Total Debt }
\end{array}
$$

The classification of a healthy and bankrupt company is based on the Altman's ZScore model, which is, as follows: (1) If the value of $Z<1.23$, including the bankrupt company; (2) If the value is $1.23<Z<2.90$, it is included in the gray area (it cannot be determined whether the company is healthy or bankrupt, but it can be said that the company is on the verge of bankruptcy); (3) If $Z>2.90$, this includes companies that are not bankrupt. Bankruptcy as the dependent variable calculated by Altman Z-Score also uses a dummy variable in which there are 2 types of samples: the company is bankrupt and the gray area because the company is on the verge of bankruptcy, then given a value of 1 and companies that are still operating or not bankrupt are given a value of 0 .

In this study, the data analysis model used is a logistic regression model or logistic regression model. Logistic regression model (logit) is a non-linear regression that produces an equation where the dependent variable is categorical. The most basic category of the model produces binary values such as the numbers 0 and 1 . The resulting number represents a certain category that results from the calculation of the probability of occurrence of that category. The analysis of this model aims to test and analyze the influence of the independent variables, namely liquidity, profitability, debt structure, solvency, and activity ratio to the dependent variable, namely Bankruptcy in SME companies listed on PEFINDO25 where the value of 0 means the company is not bankrupt or healthy and the value 1 means the company is bankrupt. 


\section{RESULT AND DISCUSSIONS}

The following are descriptive data about the research variables studied.

Table 1. Descriptive Research Variable Data

\begin{tabular}{lcrrrr}
\hline \multicolumn{1}{c}{ Variabel } & N & Minimum & Maximum & \multicolumn{1}{c}{ Mean } & \multicolumn{1}{c}{ Std. } \\
\hline BANKRUPTCY & 160 & 0 & 1 & 0.42 & 0.496 \\
LIQUIDITY & 160 & 0.3617 & 12.9946 & 2.570241 & 2.2202874 \\
PROFITABILITY & 160 & -0.0786 & 0.6011 & 0.130546 & 0.1083865 \\
DEBT & & & & & \\
STRUCTURE & 160 & 0.0691 & 1.2661 & 0.458544 & 0.2175293 \\
SOLVENCY & 160 & -2.4817 & 5.5815 & 0.066177 & 0.5727390 \\
ACTIVITY RATIO & 160 & 0.0990 & 3.1891 & 0.971202 & 0.6130647 \\
SIZE & 160 & 26.1684 & 30.0122 & 28.333864 & 0.7902940 \\
AGE & 160 & 1.0792 & 1.6812 & 1.459316 & 0.1464612 \\
\hline
\end{tabular}

Based on the results of calculations in table 6 it can be seen that $32 \mathrm{SME}$ companies that were sampled in this study using the Pooled Data method or panel data, in which 32 SME companies were multiplied by the 2013-2017 observation year period with a total of 160 observations. Based on the table obtained namely the dependent variable, Bankruptcy, has an average of 0.42 with a standard deviation of 0.496. The maximum Liquidity value of 12,9946 was owned by PT Semen Baturaja Tbk in 2014 and the minimum value of 0.3617 was owned by PT Sarana Meditama Metropolitan Tbk in 2013. The average value of Liquidity was 2.570241. While the standard deviation value away from the zero figure of 2.2202874 shows that the spread of Liquidity data varies (varies). The maximum profitability value of 0.6011 is owned by PT Matahari Department Store Tbk in 2015, and the minimum value of 0.0786 is owned by PT Express Transindo Utama Tbk in 2017. The average value of profitability is 0.130546 while the standard deviation value away from zero is 0.1083865 shows that Profitability data distribution varies (varies). The maximum Debt Structure value of 1.2661 was owned by PT Matahari Department Store Tbk in 2013, and the minimum value of 0.0691 was owned by PT Industri Jamu and Pharmaceutical Sidomuncul Tbk in 2014. The average value of Debt Strucrure was 0.458544 . While the standard deviation value away from zero of 0.2175293 shows that the spread of Debt Structure data varies (varies).

The maximum Solvency value of 5.5815 was owned by PT Semen Baturaja Tbk in 2013, and the minimum value of -2.4817 was owned by PT Industri Jamu and Pharmacy Sidomuncul Tbk in 2014. The average value of Solvency was 0.066177 . While the standard deviation value away from the zero figure of 0.5727390 shows that the distribution of Solvency data varies (varies). The maximum value of the Activity ratio of 3,1891 was owned by PT Metrodata Electronics Tbk in 2013, and the minimum value of 0.0990 was owned by PT Gozco Plantation Tbk in 2015. The average value of the Activity ratio was 0.971202 . While the standard deviation value away from zero is 0.6130647 indicating that the spread of Activity ratio data varies (varies). The maximum Size value of 30,0122 is owned by PT Metrodata Electronics Tbk Tbk in 2017 and the minimum value of 26,1684 is owned by PT Express Transindo Utama Tbk in 2017. The average value of Size is $28,333,864$. While the standard deviation value away from zero is 0.7902940 indicating that Size data distribution varies (varies). The maximum age value of 1.6812 was owned by PT Elnusa Tbk in 2017, and the minimum value of 1.0792 was owned by PT Gozco Plantation in 2013. The average age value was 1.459316 . While the standard deviation value away from the zero value of 0.1464612 shows that the spread of age data varies (varies). 
Table 2. Test Results (Partial Test)

\begin{tabular}{lrrc}
\hline \multicolumn{1}{c}{ Variabel } & z-statistic & $\mathbf{p}^{*}$ & Result \\
\hline LIQUIDITY & -2.154 & 0.000 & Significant \\
PROFITABILITY & -28.587 & 0.000 & Significant \\
DEBT STRUCTURE & 5.009 & 0.024 & Significant \\
SOLVENCY & -1.411 & 0.310 & Not significant \\
ACTIVITY RATIO & -1.149 & 0.113 & Not significant \\
SIZE & 0.491 & 0.337 & Not significant \\
AGE & -4.747 & 0.037 & Significant \\
\hline
\end{tabular}

From the results of the $t$ test obtained a $p$-value of 0,000 is smaller than $\alpha 0.05$ so it is said to be significant. The regression coefficient for the liquidity variable is -2.154 . It can be concluded that there is a significant and negative effect between Liquidity on Bankruptcy. These results indicate that the greater the liquidity calculated by the current ratio, the less likely the company to go bankrupt. Corporate liquidity shows the company's ability to fund its operations and pay off short-term obligations. The results of this study are in line with what Abdullah (2015) has stated that there is a negative relationship between liquidity and bankruptcy. Companies with high liquidity ratios, indicate that the company can manage well, the use of current assets, such as cash, accounts receivable, and inventory to be able to cover the company's short-term liabilities effectively which will affect good financial conditions as well, so it will not happen financial failure at the company. The company will get better in covering its short-term debt if the current assets owned by the company are high (Cultrera \& Bredart 2016).

From the $t$ test results obtained $p$-value of 0,000 is greater than $a 0.05$ so it can be said to be significant. The value of the regression coefficient for the profitability variable is $-28,587$. It can be concluded that there is a significant and negative effect between profitability on Bankruptcy. These results indicate the higher the profitability of the company, the smaller the risk of bankruptcy experienced by the company. That is because the ability to obtain a higher corporate profits will affect good financial conditions so that there will be no financial failure at the company. That is because the ability to obtain a higher corporate profits will affect good financial conditions so that there will be no financial failure at the company. The results of this study are in line with research conducted by Cultrera et al. (2017) concluded that there is a negative relationship between profitability and bankruptcy. This ratio measures the amount of profits or profits generated by the company, because the higher the profit earned by the company, the company will be more protected from the risk of bankruptcy. Companies that have a high level of profitability indicate that the company will be able to produce maximum profits, which can be used in various ways, both to fund all of the company's activities, and pay its obligations. Thus it can be said that the company can avoid the risk of bankruptcy. The effectiveness of the use of assets to be able to generate profits from both sales and investment will make the company survive and avoid the risk of bankruptcy.

From the t test results obtained $p$-value of 0.024 is greater than $\alpha 0.05$ so it can be said to be significant. The regression coefficient for the debt structure variable is 5,009 . It can be concluded that there is a significant and positive influence between Debt Structure on Bankruptcy. These results indicate the higher the debt structure owned by the company, the greater the possibility of bankruptcy risk that will be experienced by the company. This finding also shows that perhaps the amount of debt decided to be handled by the company could be one of the determining factors that might force certain companies to surrender to an unhealthy condition of the company 
and have to make a turnaround (a reversal of the company's direction of performance decline) (Abdullah \& Zolkafli 2010). In theory, if the ratio of debt owned by a small company, the company can effectively repay both long and short term debt, but the results of this study are inversely proportional to the theory that SME companies have a large debt structure, the more likely the company is experiencing bankruptcy risk. SME companies that experience financial failures generally have the same amount of debt as the total assets and even have a larger amount of debt than the total assets. Large amounts of debt usually have negative equity. Then do not rule out the possibility that companies experiencing these conditions will violate the debt agreement with the creditor because the amount of assets held cannot guarantee it (Moro et al. 2012).

From the t test results obtained $p$-value of 0.310 is greater than $\alpha 0.05$ so it can be said to be insignificant. It can be concluded that there is no significant effect between Solvency on Bankruptcy. These results indicate that the size of the company's solvency ratio does not affect the risk of bankruptcy that will be experienced by the company. The reason for the absence of the influence of cash flow on bankruptcy is due to conditions where the company has a typical fluctuating flow that is sometimes extreme, where in a period the company has very low cash flow but in the next period the cash flow owned by the company is very high. If the change occurs within an interval of one period, then the company will experience a loss in one period but in the next period will experience profits, or vice versa. Because only one time interval occurs fluctuations, the company tends not to be considered bankrupt (Cultrera \& Bredart 2016).

From the t test results obtained $p$-value of 0.113 is greater than $\alpha 0.05$ so it can be said to be insignificant. It can be concluded that there is no significant effect between Activity Ratio on Bankruptcy. These results indicate that the high and low activity ratio of a company does not affect the risk of bankruptcy in that company. Although in theory it is said that increasing the company's sales volume will increase the company's profit used in operational activities and can cover the company's obligations, so that the company can avoid the risk of bankruptcy. However, with high sales volume without being accompanied by cost efficiency will not increase profits. The increase in sales is accompanied by a greater increase in costs so that the expected profit is not achieved so that the company's ratio does not affect the risk of bankruptcy.

From the t test results obtained $p$-value of 0.337 is greater than $\alpha 0.05$ so it can be said to be insignificant. It can be concluded that there is no significant effect between Size on Bankruptcy. These results indicate that a large size company does not guarantee to reduce the possibility of bankruptcy in SME companies, but a small company size is also not necessarily not experiencing bankruptcy risk, because it all depends on management how management can utilize existing assets effectively and efficiently in order to used in the company's operations to get the maximum profit, so that it can cover the company's obligations (Situm 2014).

From the t test results obtained $p$-value of 0.037 is greater than $\alpha 0.05$ so it can be said to be insignificant. The regression coefficient for the age variable is -4.747 . It can be concluded that there is a significant and negative influence between Age on Bankruptcy. These results indicate that with increasing age, companies can reduce the risk of bankruptcy. A company that has been established for a long time or is old has experience in the field of business, both in terms of management and finance so that the company can survive, to produce high sales volumes to enable rapid growth of the company compared to younger companies. This result is in accordance with Tulsian (2014) which argues that there is a negative relationship between age and bankruptcy, 
due to the increasing age of the company. companies can avoid the risk of bankruptcy (Cultrera \& Bredart 2016).

Table 3. Results of the Omnibus Test of Model Coefficient

\begin{tabular}{llll}
\hline Step & Chi-Square & Df & Sig \\
\hline 1 & 139.632 & 7 & 0.000 \\
\hline
\end{tabular}

From the test results in the table above, obtained a chi-square of significant value of 139,632 and df 7 of these results it appears that the significant value is less than 0.05 so the null hypothesis is rejected, which means the independent variables jointly influence the dependent variable. So the results of simultaneous testing in this study is that there is an effect of Liquidity, Profitability, Debt Structure, Solvency, Activity ratio, Size, and Age together on Bankruptcy.

\section{CONCLUSSION}

The conclusions in this study are Liquidity, Profitability and Age have a significant negative effect on bankruptcy while debt structure has a significant positive effect on bankruptcy. Besides solvency, activity ratio and size do not have a significant effect on bankruptcy. Overall namely liquidity, profitability, debt structure, solvency, activity ratio, firm size, and age together have a significant effect on bankruptcy. Companies must consider liquidity, profitability, and debt structure if they want to avoid the risk of transportation. If the company has a high liquidity ratio and profitability ratio, it will reduce the probability of bankruptcy risk. This is because the liquidity ratio is the company's ability to pay off all its short-term obligations with the use of its current assets so that if the company can produce large assets, the company can cover its obligations. While the low debt structure of the company indicates that the use of the company's long-term debt is not too large so that the company can fulfill its debt obligations. Besides profitability ratio is a ratio to measure the company's ability to obtain maximum profit so as to reduce the possibility of bankruptcy risk in the company.

Investors should consider financial ratios which are important factors so that the company can avoid the risk of bankruptcy. Companies that want to invest capital in companies can see the profitability, liquidity and debt structure of the company contained in the company's financial statements and annual reports. If the company has a high profitability and liquidity ratio, the level of investment returns that will be obtained by investors will tend to be high. With this, investors can find out how the actual condition of the company and can get the maximum benefit from investments made in the company. It is hoped that this research can contribute to the study of the effect of Liquidity, Profitability, Debt Structure, Solvency, Activity ratio, Size damage to Bankruptcy, especially in SME companies listed on PEFINDO25 and can be used as additional knowledge for further research.

\section{ACKNOWLEDGMENTS}

Researchers would like to thank the parents, brothers and sisters who always patiently offered prayer, affection, love and moral support that was very big and always prayed for success during the study. In addition, the researchers also thanked the supervisor and assistant lecturer for all forms of assistance, guidance, and direction so that the journal was completed properly, as well as all teaching lecturers and graduate staff of Master of Management at Trisakti University and friends of the Masters in Management concentration in Management Finance and Regular class 48 and also the friends who always support and pray for in completing this journal. 


\section{REFERENCES}

Abdullah, M. (2015). Empirical analysis of liquidity, profitability and solvency of bangladesh banks. Journal of business and financial affairs, 4(3): 1-12.

Abdullah, T. M. C., Zolkafli, H. (2010). Predicting corporate turnaround using logistic regression analysis: A Research on Bursa Malaysia Companies. Journal of management and business, 9(2): 214-226.

Cultrera, L., Croquet, M., Jospin, J. (2017). Predicting bankruptcy of Belgian SMEs: A Hybrid approach based on factorial analysis. International research, 10(3): 33-41.

Cultrera, L., Bredart, X. (2016). Bankruptcy Prediction: The case of Belgian SMEs. Review of accounting and finance 14(1): 101-119.

Kristiyanti, Mariana. (2012). Peranan strategis usaha kecil menengah (UKM) dalam pembangunan nasional. Majalah ilmiah informatika, 3(1): 63- 89.

Lukason, O., Laitinen, E. K., Suvas, A. (2016). Failure processes of young manufacturing micro firms in Europe, Management Decision, 5(8): 1966-1985.

Moro, A., Lucas, M., Grassi, E., Bazzanela, C. (2012). The short-term debt vs long term debt puzzle: a model for this optimal mix. Conference on performance measurement and management control, 5.

Nouiri, B. A., Soltani, M. (2017). Designing a bankruptcy prediction model based on account, maket and macroeconomic variables (case study: Cyrus Stock Exchange). Iranian Journal of Management Studies, 9(1): 125-147.

Odibi, L., Basit, A., Hassan, Z. (2015). Bankruptcy prediction using Almant Z-Score model: a case of public listed manufacturing companies in Malaysia. International journal of accounting and business management, 3(2): 178-186.

Situm, Mario. (2014). The age and size of the firm as relevant predictors for bankruptcy. Journal of applied economics and business, 2(2): 5-30.

Tulsian, M. (2014). Profitably analysis (a comparative study of SAIL and TATA steel. IOSR journal of economics and finance, 3(2): 19-22. 